Розроблено активні та селективні каталізатори на основі оксидів бору $і$ фосфору, промотовані оксидами цирконію, вольфраму $і$ вісмуту, процесу газофазної сумісної конденсацї̈ пропіонової кислоти і метилпропіонату 3 формальдегідом із утворенням метакрилової кислоти та метилметакрилату. Визначено оптимальну температуру процесу. Встановлено, що при додаванні метанолу зростає співвідношення метилметакрилату до метакрилової кислоти у продуктах і сумарна селективність процесу

Ключові слова: метакрилова кислота, метилметакрилат, пропіонова кислота, альдольна конденсачія, каталізатор, метилпропіонат, формальдегід

Разработаны активные и селектив ные катализаторы на основе оксидов бора и фосфора, промотированного оксидами циркония, вольфрама и висмута, процесса газофазной совместной конденсации пропионовой кислоты и метилпропионата с формальдегидом с образованием метакриловой кислоты и метилметакрилата. Определена оптимальная температура процесса. Установлено, что при добавлении метанола увеличивается соотношение метилметакрилата к метакриловой кислоте в продуктах и суммарная селективность процесса

Ключевые слова: метакриловая кислота, метилметакрилат, пропионовая кислота, альдольная конденсация, катализатор, метилпропионат, формальдегид

$\square$
UDC 541.128.13

DOI: $10.15587 / 1729-4061.2016 .79429$

\section{SYNTHESIS OF ACRYLATES FROM METHYL PROPIONATE, PROPIONIC ACID AND FORMALDEHYDE IN THE GAS PHASE ON SOLID CATALYSTS}

\author{
N. La p y chak \\ Postgraduate Student* \\ E-mail: glominik@gmail.com \\ V. I v a s iv \\ $\mathrm{PhD*}$ \\ E-mail: el.spectre.x@gmail.com \\ R. Ne bes n y i \\ $\mathrm{PhD*}$ \\ E-mail: nebesnyi@|p.edu.ua \\ Z. P i k h \\ Doctor of Chemistry Science, Professor* \\ E-mail: pikh@polynet.Iviv.ua \\ I. S h p y r k a \\ Postgraduate Student* \\ E-mail: irynashpirka@gmail.com \\ *Department of Technology of Organic Products \\ Lviv Polytechnic National University \\ Bandera str., 12, Lviv, Ukraine, 79013
}

\section{Introduction}

Acrylates occupy a prominent place in the industry of organic synthesis. The main area of their use is the fabrication of acrylate polymers, which owing to their valuable technical properties such as transparency, mechanical strength, ductility, thermal resistance have found applications in various spheres of human activity. Of particular value are the methyl methacrylate (MMA) and methacrylic acid (MAA), from which a number of important products and semi-products such as polymers, solvents, and plasticizers are obtained. The MMA copolymers with MAA or acrylic acid are used for producing noise insulation and fire-resistant polymers, in cosmetology. Every year acrylates are more and more applied in medicine, in the production of pigment materials and other areas. It is forecasted that by 2022 manufacturing of acrylates and the total volume of their consumption will grow annually by $6.3 \%$, therefore, a relevant task is the design and improvement of methods of obtaining acrylate monomers for implementation of the technology of their production in Ukraine. That is why the development of catalytic systems for the multiton production of acrylates by the suggested method is of large practical value and importance.
2. Literature review and problem statement

Existing methods of obtaining acrylate monomers have a number of shortcomings - producing large amounts of by-products of oxidation, formation of toxic wastes, as well as a big number of stages of the process [1,2]. It is promising to obtain acrylate monomers by aldol condensation of carbonyl compounds in the gas phase, which is characterized by a small amount of by-products, the absence of toxic waste and the availability of raw materials [3]. In particular, as an affordable raw material they use ethylene, which is produced in Ukraine as well. Currently, research into the processes of aldol condensation of propionic acid (PA) with formaldehyde (FA) in the gas phase on solid catalysts with obtaining MAA is actively conducted, and by the condensation of methyl propionate (MP) with FA - MMA and MAA.

Most of the catalysts used in the existing processes of condensation of PA or MP with FA, have typical drawbacks such as low conversion of initial reagents $[4,5]$ at relatively high selectivity, or low selectivity of formation of the target product at high conversion rate [6, 7]. The catalysts, known today, also provide high yield of the target product only at significant excess of PA or MP, which is undesirable because it increases the energy cost for recycling the raw materials 
$[8,9]$. That is why designing new active catalytic systems and determining optimal parameters of implementation of the process is an important scientific and practical task.

Papers [10,11] established that for the process of aldol condensation of MP with FA, the active boron-phosphorus-oxide catalyst was developed, applied on the silica gel, promoted by zirconium oxide $\left(\mathrm{B}_{2} \mathrm{O}_{3}: \mathrm{P}_{2} \mathrm{O}_{5}: \mathrm{ZrO}_{2}=3: 1: 0.3\right)$, however, due to the hydrolysis of part of the MP to PA and methanol, the total selectivity of the formation of acrylates is low $-65.4 \%$. The same catalyst, promoted by tungsten oxide $\left(\mathrm{B}_{2} \mathrm{O}_{3}: \mathrm{P}_{2} \mathrm{O}_{5}: \mathrm{WO}_{3}=3: 1: 0.3\right)$, proved effective in the process of aldol condensation of PA with FA, ensuring the selectivity of MAA formation at $93.5 \%$ [12]. It was determined that the use of a mixture of oxides of transition metals $\left(\mathrm{B}_{2} \mathrm{O}_{3}: \mathrm{P}_{2} \mathrm{O}_{5}: \mathrm{V}_{2} \mathrm{O}_{5}: \mathrm{WO}_{3}\right)$ as the promoters makes it possible to significantly increase the yield of acrylates [13]. The literature also has reference to the data on the use, in the process of aldol condensation of PA and FA, compounds of bismuth deposited on zeolite, which allows reaching the selectivity of MAA formation close to $100 \%$, and at a very low conversion of reagents [5]. Given the shortcomings mentioned in the considered above processes of obtaining acrylates, it is reasonable to explore a new process of combined condensation of MP and PA with FA, which on one hand should reduce the MP hydrolysis due to the presence of PA in the reaction mixture and, on the other hand, will allow to recirculate the PA that formed in the process of hydrolysis of MP. It is also advisable to examine the effect of methanol on the course of the process because this can also reduce the MP hydrolysis and increase the share of more valuable MMA in the products of the reaction. It should be noted that there are no systematic data in the literature on combined condensation of MP and PA with FA, as well as on the studies of influence of methanol on this system, hence the need to create catalysts that would provide acceptable conversion and high selectivity for the proposed process. Thus, in this work we decided to design a catalyst of the process of condensation of PA and MP with FA based on the boron-phosphorus-oxide catalyst, promoted by the mixture of zirconium oxide and tungsten oxide with their varied content, as well as individual oxides of zirconium.

\section{Aims and objectives of the research}

The aim of this work is the development of catalytic systems for obtaining methacrylic acid and methyl methacrylate by the method of compatible condensation of propionic acid and methyl propionate with formaldehyde in the gas phase.

To achieve the set goal, the following tasks were to be solved:

- to create highly selective catalysts of the process of combined condensation of propionic acid and methyl propionate with formaldehyde; process;

- to determine optimum temperature of performing the

- to determine the effect of methanol on the course of the process of gas-phase condensation of MP and PA with FA.

\section{Method of research into activity of the created catalysts in the process of condensation}

The research was carried out with the use of catalysts on the base of a mixture of oxides of boron and phosphorus with oxides of zirconium, tungsten and bismuth, applied on the silica gel. The total number of active components in the catalyst was $20 \%$ mass. The molar ratio of the oxides $\mathrm{B}_{2} \mathrm{O}_{3}: \mathrm{P}_{2} \mathrm{O}_{5}$ in the catalysts was 3:1. The content of the oxides $\mathrm{ZrO}_{2}$ and $\mathrm{WO}_{3}$ was varied so that the molar ratio of the components $\mathrm{B}_{2} \mathrm{O}_{3}: \mathrm{P}_{2} \mathrm{O}_{5}: \mathrm{ZrO}_{2}: \mathrm{WO}_{3}$ was 3:1:0.3:0.3 та 3:1:0.15:0.15 (hereinafter in the paper all the ratios are specified relative to the content of phosphorus oxide). The ratio of components in the catalysts, promoted by individual zirconium and bismuth oxides $\mathrm{B}_{2} \mathrm{O}_{3}: \mathrm{P}_{2} \mathrm{O}_{5}: \mathrm{ZrO}_{2}$ and $\mathrm{B}_{2} \mathrm{O}_{3}: \mathrm{P}_{2} \mathrm{O}_{5}: \mathrm{Bi}_{2} \mathrm{O}_{3}$ was $3: 1: 0.3$. All of the catalysts were prepared by the impregnation method [14].

The catalytic systems were examined in a flow reactor with a stationary layer of catalyst. For the research we used a mixture with the ratio of reagents MP:PA:FA=1:1:2. Two molecules of FA were chosen considering for one per every molecule of PA and MP. For the study of the process in the presence of methanol, the ratio of reagents was MP:PA:methanol:FA=1:1:1:2. As the source of FA we used formalin $37 \%$, which was prepared from paraform directly before the experiments. The temperature of the process changed in the range of $563 \div 683 \mathrm{~K}$, the residence time was $12 \mathrm{~s}$ because it was found previously that these conditions are optimal for the process of condensation of MP with FA [11-13]. The reaction products were analyzed by the gas chromatography method.

\section{Determining optimal temperature and composition \\ of the catalyst in the process of aldol condensation of methyl propionate with formaldehyde}

The research results of the process of condensation of $\mathrm{MP}$ and PA with FA in the presence of $\mathrm{B}_{2} \mathrm{O}_{3}-\mathrm{P}_{2} \mathrm{O}_{5} / \mathrm{SiO}_{2}$ catalytic system with different promoters allowed us to establish that the conversion of ester and acid increases with increasing temperature in the presence of all examined catalysts (Fig. 1). The maximum conversion value of $83 \%$ was obtained at the catalyst, promoted by zirconium and tungsten oxides with the molar ratio $\mathrm{ZrO}_{2}: \mathrm{WO}_{3}=0.3: 0.3$ at a temperature of $683 \mathrm{~K}$.

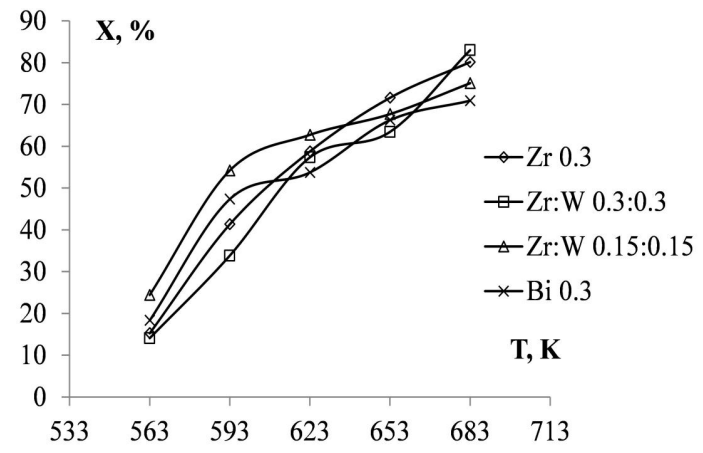

Fig. 1. Dependency of the total conversion of methyl propionate and propionic acid (X, \%) on temperature $(\mathrm{T}, \mathrm{K})$ in the presence of catalysts with different promoters

The total selectivity of formation of MMA and MAA decreases with increasing temperature (Fig. 2). The highest values of selectivity are achieved at temperatures of 563-593 K on all the examined catalysts. This is due to the fact that at temperatures over $623 \mathrm{~K}$, the process of formation of a by-product, diethyl ketone, actively occurs. The maximum total selectivity of formation of MAA and MMA is $96.4 \%$ 
at a temperature of $593 \mathrm{~K}$ in the presence of the catalyst, promoted by oxides of zirconium and tungsten with the molar ratio $\mathrm{ZrO}_{2}: \mathrm{WO}_{3}=0.15: 0.15$. It is also worth noting that the catalyst, promoted by bismuth oxide, at a temperature in the range of $562-623 \mathrm{~K}$ also provides a high selectivity of $96 \%$, but the conversion of reagents under these temperatures is lower.

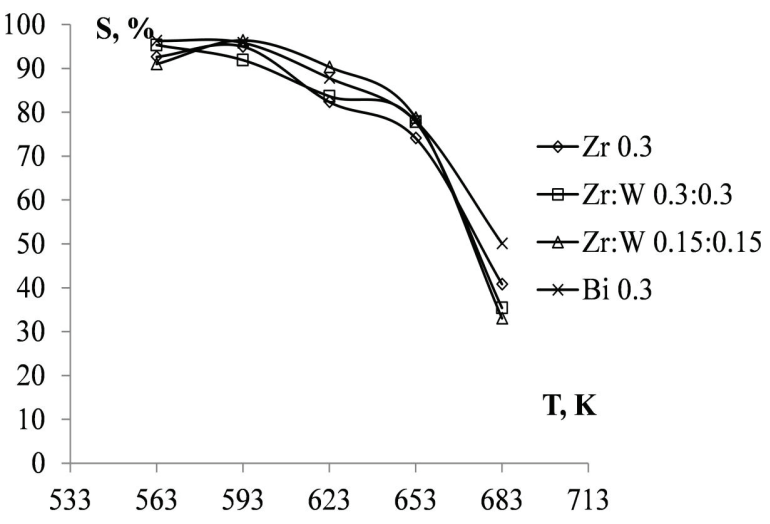

Fig. 2. Dependency of the total selectivity of formation of methyl methacrylate and methacrylic acid (S, \%) on temperature $(T, K)$ in the presence of catalysts with different promoters

The total yield of the unsaturated products significantly increases with increasing temperature to $653 \mathrm{~K}$ on all of the examined catalysts (Fig. 3). When the temperature exceeds $653 \mathrm{~K}$, the total yield of MMA and MAA is reduced due to a decrease in the selectivity of formation of the target products and increase in the output of by-products at high temperatures. The highest yield of products was obtained in the presence of the catalyst, promoted by oxides of zirconium and tungsten with the molar ratio $\mathrm{ZrO}_{2}: \mathrm{WO}_{3}=0.15: 0.15$ at a temperature of $623 \mathrm{~K}-56.7 \%$. The optimum temperature of the course of the process is considered to be $593 \mathrm{~K}$, at which the yield is $52.3 \%$ since at this temperature the largest selectivity was reached, whereas implementation of the process at $623 \mathrm{~K}$, despite providing for higher yield, requires higher energy costs and has lower selectivity of formation of the target products. In case of recycling of non consumed reagents in this process the yield of the target products will amount up to $96.4 \%$.

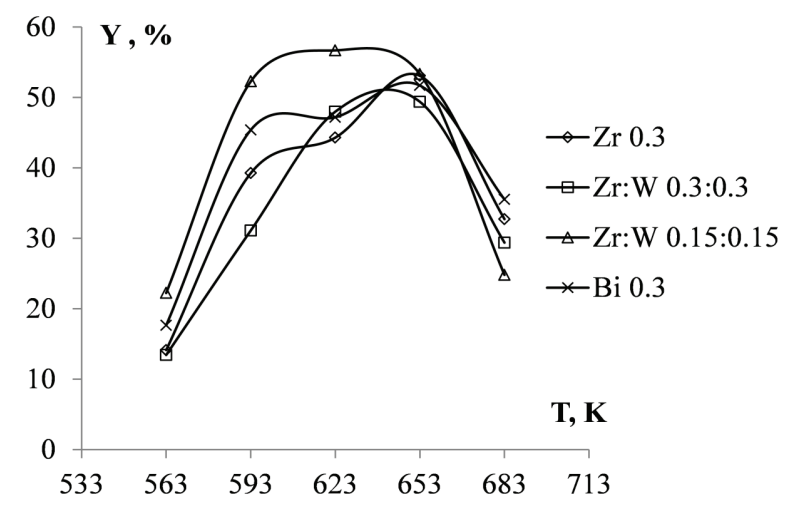

Fig. 3. Dependency of the total output of MMA and MAA $(Y, \%)$ on the temperature $(T, K)$ in the presence of catalysts with different promoters

In general, the effect of temperature of the examined process is as follows: with the increasing temperature, the conversion increases, the selectivity of formation of acrylates decreases, and the total yield of acrylates has the maximum.

Important is also the ratio of the obtained target products MMA/MAA, which in the case of the examined catalysts is low. Given that MMA is a more valuable product, we studied the effect of adding methanol to the reaction mixture with the purpose of increasing the share of MMA in the obtained products.

It was found that the addition of methanol makes it possible to increase the ratio of MMA/MAA (Fig. 4), indicating the increasing selectivity of the MMA formation. Interesting is the fact that on the catalysts, promoted by oxides of zirconium and tungsten with the molar ratio $\mathrm{ZrO}_{2}: \mathrm{WO}_{3}=0.15: 0.15$, which was the best in the process without methanol, the ratio of MMA/MAA increased significantly. Instead, on the catalysts, promoted by individual oxides of zirconium and bismuth, the use of methanol only slightly increases the ratio of MMA/MAA. The highest value was reached at a temperature of $623 \mathrm{~K}$ on the catalyst, promoted by mixtures of oxides of zirconium and tungsten.

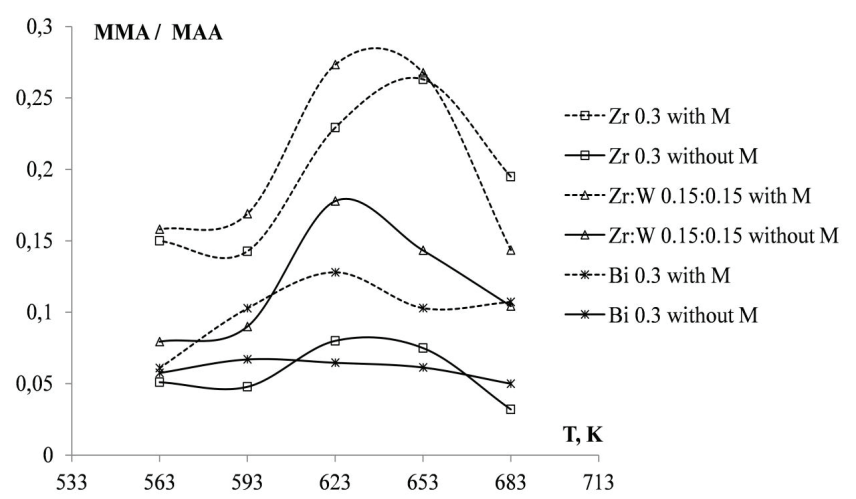

Fig. 4. Dependency of the ratio of MMA/MAA on temperature $(T, K)$ with and without adding of methanol

We also determined the total selectivity and the total yield of the target products in the presence of methanol (Fig. 5, 6). Adding methanol not only increases the ratio of MMA/MAA but also increases the total selectivity of formation of acrylates. In particular, at temperatures of $563-593 \mathrm{~K}$ on the catalyst, promoted by bismuth oxide, the total selectivity reaches $100 \%$. Given that the conversion at these temperatures reaches $33 \%$, the total yield is $33 \%$ accordingly. This allows for designing the technological process without formation of by-products, albeit with a lower conversion of reagents. The maximum value of the total output was reached on the catalyst, promoted by bismuth oxide, at a temperature of $653 \mathrm{~K}$. However, at a temperature of $623 \mathrm{~K}$, the selectivity is slightly higher and the yield is only slightle lower, so the temperature $623 \mathrm{~K}$ can be considered optimal. The total yield and selectivity of the acrylates formation on the catalyst, promoted by bismuth oxide, at this temperature are $51.5 \%$ and $91.6 \%$, respectively.

It should also be noted that the catalyst, promoted by oxides of tungsten and zirconium with the molar ratio $\mathrm{ZrO}_{2}: \mathrm{WO}_{3}=0.3: 0.3$, displayed worse results than $\mathrm{ZrO}_{2}: \mathrm{WO}_{3}=0.15: 0.15$ in the process without using methanol, so the process on this catalyst in the presence of methanol was not examined. 


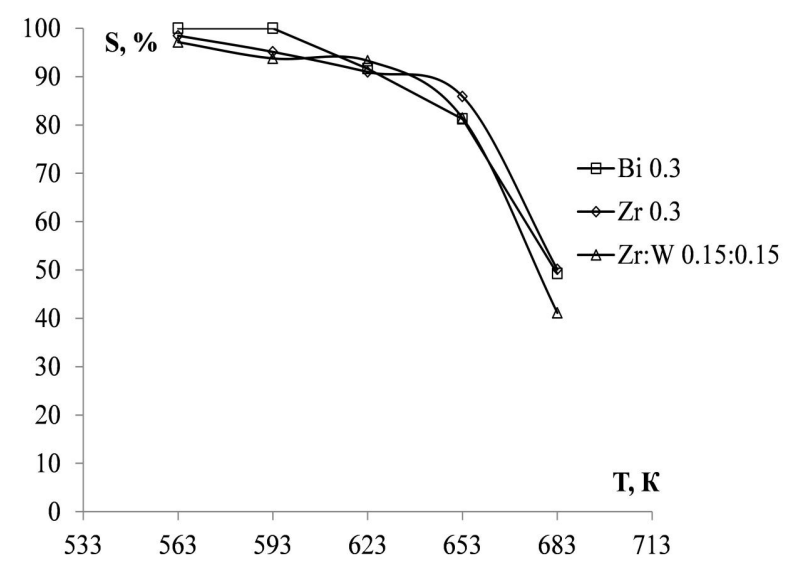

Fig. 5. Dependency of the total selectivity of the MMA/MAA formation (S, \%) on temperature $(T, K)$ in the presence of methanol

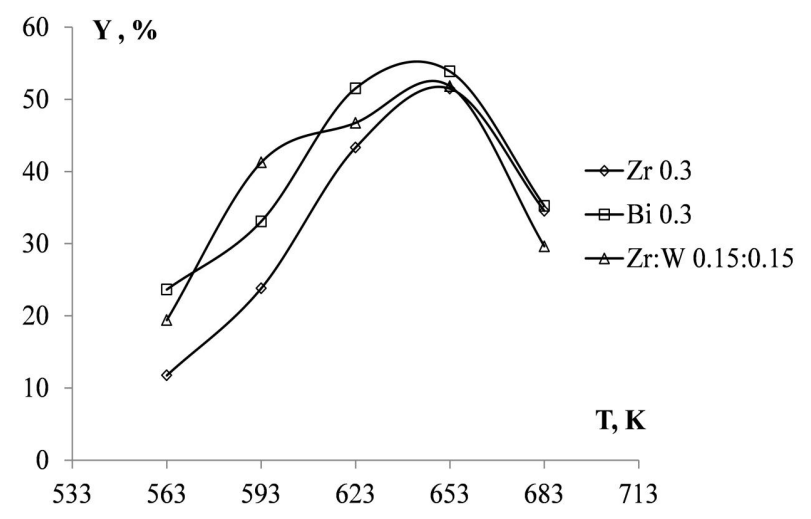

Fig. 6. Dependency of the total yield of MMA and MAA $(\mathrm{Y}, \%)$ on the temperature $(\mathrm{T}, \mathrm{K})$ in the presence of methanol

\section{Discussion of results of the research into the process of} combined obtaining MMA and MAA

The performed studies reveal that the catalytic systems $\mathrm{B}_{2} \mathrm{O}_{3}-\mathrm{P}_{2} \mathrm{O}_{5} / \mathrm{SiO}_{2}$ with selected promoters are active and highly selective in the process of aldol condensation of methyl propionate and propionic acid with formaldehyde in the gas phase. Compared to the previously studied catalysts for the process of condensation of MP and FA, promoted by individual tungsten oxide and zirconium oxide, the developed catalysts provide for a much higher selectivity of formation of the target products - methyl methacrylate and methacrylic acid. For example, in the presence of the $\mathrm{B}_{2} \mathrm{O}_{3}-\mathrm{P}_{2} \mathrm{O}_{5}-\mathrm{WO}_{3} / \mathrm{SiO}_{2}$ catalyst, the maximum selectivity of formation of acrylates reached $49.1 \%$ and was achieved at a temperature of $653 \mathrm{~K}$ [12], while in the presence of the $\mathrm{B}_{2} \mathrm{O}_{3}-\mathrm{P}_{2} \mathrm{O}_{5}-\mathrm{ZrO}_{2} / \mathrm{SiO}_{2}$ catalyst, the selectivity is $65.4 \%$ at a temperature of $623 \mathrm{~K}$ [13]. Thus, the designed $\mathrm{B}_{2} \mathrm{O}_{3}-\mathrm{P}_{2} \mathrm{O}_{5} / \mathrm{SiO}_{2}$ catalytic system promoted by $\mathrm{ZrO}_{2}: \mathrm{WO}_{3}=0.15: 0.15$ allowed us to increase the selectivity of formation of the target products to $96.4 \%$, which is $31 \%$ higher, and made it possible to carry out the process of condensation of MP and PA with FA at a lower optimum temperature of $593 \mathrm{~K}$ than in the process without propionic acid, confirming possibility and feasibility of the $\mathrm{PA}$ recycling in the process of condensation of MP and FA.
It was found that increase of the of MMA/MAA ratio with the addition of methanol to rection mixture was higher in the presence of a catalyst promoted by mixture of $\mathrm{ZrO}_{2}$ and $\mathrm{WO}_{3}$, than on the catalysts promoted by individual bismuth oxide and zirconium oxide. In addition, despite the fact that at the optimum temperature of $593 \mathrm{~K}$ total selectivity of acrylates decreases by $3 \%$, and the yield by $11 \%$, however substantially larger MMA yield in the products is obtained. At temperatures of $623-653 \mathrm{~K}$, there is a slight rise in the selectivity by $3-4 \%$, but the yield in this case remains lower in comparison to the process without adding methanol. This necessitates further research, in particular of the effect of change in the amount of content of methanol in the process.

Adding methanol to the initial mixture makes it possible to reach total selectivity of MMA and MAA $100 \%$ on the catalyst promoted by bismuth oxide, which allows for designing of the waste-free process, but with a lower yield of the target products. Also, adding methanol leads to some increase of the total yield of the target products on the bismuth-containing catalyst in the range of all temperatures. As far as the zirconium-containing catalyst is concerned, adding methanol also increases the total selectivity of formation of MMA and MAA, but the yield in this case is slightly reduced. The shortcoming of using methanol is that its adding to the reaction mixture decreases the conversion of reagents MP and PA.

Thus, from the results of research into combined condensation of propionic acid and methyl propionate with formaldehyde that are presented above, we can conclude that the best catalyst in terms of the yield of the target products is the $\mathrm{B}_{2} \mathrm{O}_{3}-\mathrm{P}_{2} \mathrm{O}_{5} / \mathrm{SiO}_{2}$ catalytic system with the addition of promoters $\mathrm{ZrO}_{2}: \mathrm{WO}_{3}=0.15: 0.15$ in the process without methanol in the original reagent mixture, and it is also the best by the fraction of MMA in the products in the process with the addition of methanol. Highest total selectivity and yield was obtained on the catalyst promoted by bismuth oxide, but the share of MMA in products is much lower.

In general, at low temperatures all four designed catalysts are sufficiently selective and may be used in the process of aldol condensation of MP and PA with FA in the presence of methanol or without it. The obtained results will be used for development of the technology basics for production of methyl methacrylate and methacrylic acid, particularly for designing the technological scheme and optimization of the process. In the case of methanol being added as a reagent in the reagent mixture, the overall conversion of the process is slightly reduced, which is a drawback of the proposed method. In further research, it will be necessary to explore effect of the residence time on the process of obtaining MMA and MAA as well as using different mixtures of oxides of metals of acid and base type as promoters to the boron-phosphorus catalyst with the purpose of increasing the share of MMA in products since it is known that the use of basic oxides increases the selectivity of formation of the target products [5].

\section{Conclusions}

1. We created highly selective catalysts of combined condensation of methyl propionate and propionic acid with formaldehyde. The selectivity of the formed catalysts varies within $90-96 \%$ in the process without the use of methanol. 
2. The optimal temperature was determined of the process of condensation of propionic acid and methyl propionate with formaldehyde, which is $593 \mathrm{~K}$. At this temperature on the catalyst with the molar ratio $\mathrm{B}_{2} \mathrm{O}_{3}: \mathrm{P}_{2} \mathrm{O}_{5}: \mathrm{ZrO}_{2}: \mathrm{WO}_{3}=3: 1: 0.3: 0.15: 0.15$, the single-pass yield of methyl methacrylate and methacrylic acid is $52.3 \%$ with the total selectivity of their formation at $96.4 \%$.

3. It was established that adding methanol to the reagent mixture increases the ratio of methyl methacrylate to meth- acrylic acid in the products and the overall selectivity of the process on all catalysts. In particular, at a temperature of $593 \mathrm{~K}$ on the $\mathrm{B}_{2} \mathrm{O}_{3}: \mathrm{P}_{2} \mathrm{O}_{5}: \mathrm{Bi}_{2} \mathrm{O}_{3}=3: 1: 0.3$ catalyst, total selectivity of the target products is $100 \%$ at a conversion of $33 \%$. It was found that in the process with methanol on the catalyst, promoted by zirconium and tungsten oxides, the share of MMA is the largest and the optimum temperature is $623 \mathrm{~K}$, at which the single-pass yield of MMA and MAA is $46.7 \%$ at the total selectivity of their formation of $93.3 \%$.

\section{References}

1. Process for producing methyl methacrylate [Text] / Inoue G., Baba K., Moritou T. - United States Patent Application 20020188151, published: 12.12.2002, number US 2002/0188151 A1.

2. Process for producing methyl methacrylate [Text] / Higuchi H., Kida,K. - European Patent Application EP0407811, published: 16.01.1991, number 0407811 A2.

3. Nagai, K. New developments in the production of methyl methacrylate [Text] / K. Nagai // Applied Catalysis A: General. - 2001. Vol. 221, Issue 1-2. - P. 367-377. doi: 10.1016/s0926-860x(01)00810-9

4. Ai, M. Formation of methyl methacrylate by condensation of methyl propionate with formaldehyde over silica-supported cesium hydroxide catalysts [Text] / M. Ai // Applied Catalysis A: General. - 2005. - Vol. 288, Issue 1-2. - P. 211-215. doi: 10.1016/ j.apcata.2005.04.027

5. Li, J. Hydrocarbon oxidation and aldol condensation over basic zeolite catalysts [Text] / J. Li, J. Tai, R. J. Davis // Catalysis Today. 2006. - Vol. 116, Issue 2. - P. 226-233. doi: 10.1016/j.cattod.2006.01.032

6. Ai, M. Formation of methyl methacrylate from methyl propionate and methanol [Text] / M. Ai // Catalysis Today. - 2006. Vol. 111, Issue 3-4. - P. 398-402. doi: 10.1016/j.cattod.2005.10.053

7. Tai, J. Synthesis of methacrylic acid by aldol condensation of propionic acid with formaldehyde over acid-base bifunctional catalysts [Text] / J. Tai, R. J. Davis // Catalysis Today. - 2007. - Vol. 123, Issue 1-4. - P. 42-49. doi: 10.1016/j.cattod.2007.02.004

8. Gogate, M. R. Synthesis of methyl methacrylate by vapor phase condensation of formaldehyde with propionate derivatives [Text] / M. R. Gogate, J. J. Spivey, J. R. Zoeller // Catalysis Today. - 1997. - Vol. 36, Issue 3. - P. 243-254. doi: 10.1016/s09205861(96)00241-6

9. Jang, B. W.-L. Synthesis of methacrylates from Coal-derived Syngas [Electronic resource] / B. W.-L. Jang, J. R. Zoeller, J. J. Spivey, R. D. Colberg, M. R. Gogate, G. N. Choi. - Available at: http://www.osti.gov/scitech/servlets/purl/774948

10. Dmytruk, Yu. Optimum conditions determination of methyl methacrylate obtaining over tungsten-containing catalyst [Text] / Yu. Dmytruk, V. Ivasiv, R. Nebesnyi, S. Maykova // Eastern-European Journal of Enterprise Technologies. - 2015. - Vol. 4, Issue 6(76). - P. 4-7. doi: 10.15587/1729-4061.2015.47955

11. Nebesna, Yu. V. The study of technological and kinetic regularities of simultaneous methacrylates obtaining over zirconiumcontaining catalysts [Text] / Yu. V. Nebesna, V. V. Ivasiv, R. V. Nebesnyi // Eastern-European Journal of Enterprise Technologies. 2015. - Vol. 5, Issue 6 (77). - P. 4-52. doi: 10.15587/1729-4061.2015.51348

12. Nebesnyi, R. The kinetic of the gas phase aldol condensation reaction of propionic acid with formaldehyde on $\mathrm{B}_{2} \mathrm{O}_{3}-\mathrm{P}_{2} \mathrm{O}_{5}-\mathrm{WO}_{3} / \mathrm{SiO}_{2}$ catalyst [Text] / R. Nebesnyi, V. Ivasiv, Z. Pikh, V. Zhyznevskyi, Y. Dmytruk // Chemistry \& Chemical Technology. - 2014. - Vol. 8, Issue 1. - P. 29-34.

13. Nebesnyi, R. Complex oxide catalysts of acrylic acid obtaining by aldol condensation method [Text] / R. Nebesnyi // EasternEuropean Journal of Enterprise Technologies. - 2015. - Vol. 1, Issue 6 (73). - P. 13-16. doi: 10.15587/1729-4061.2015.37405

14. Ding, S. Condensation of Methyl Propionate with Formaldehyde to Methyl Methacrylate over Cs- $\mathrm{Zr}-\mathrm{Mg} / \mathrm{SiO} 2 \mathrm{Catalysts}$ [Text] / S. Ding, L. Wang, R. Y. Yan, Y. Y. Diao, Z. X. Li, S. J. Zhang, S. J. Wang // Advanced Materials Research. - 2012. - Vol. 396-398. P. 719-723. doi: 10.4028/www.scientific.net/amr.396-398.719 